\title{
John William \\ Magladery \\ 1911-1977
}

John W. Magladery was born in New Liskeard, Ontario on October 11,1911 . He graduated from Upper Canada College in 1929 and the University of Toronto Medical School in 1935. As a Rhodes scholar, he received the degree of $\mathrm{D}$. Phil. in Neurophysiology from Oxford University in 1937. During World War II, he was a major in the Royal Canadian Army Medical Corps. Post-graduate studies were undertaken at the University of Toronto and the National Hospital, Queen Square.

In 1946, he came to Baltimore and until 1969 served as Chairman of the Division of Neurology at The Johns Hopkins School of Medicine. During this period, he trained a number of residents and post-graduate fellows in Neurology at the Baltimore City Hospitals and The Johns Hopkins Hospital. His research interests were extensive, often combining basic Neurophysiology and Clinical Neurology. Notable contributions in humans included the $\mathrm{H}$ reflex, the corneal, abdominal, plantar and other reflexes as well as the original description of the $F$ wave.

After a brief illness, he died on December 27, 1977. He is survived by his wife, Virginia and two children, Sarah and John.

The article on the Crossed Adductor Reflex which appears in this Journal incorporates some of his thoughts and is dedicated to Dr. Magladery.

Robert D. Teasdall 